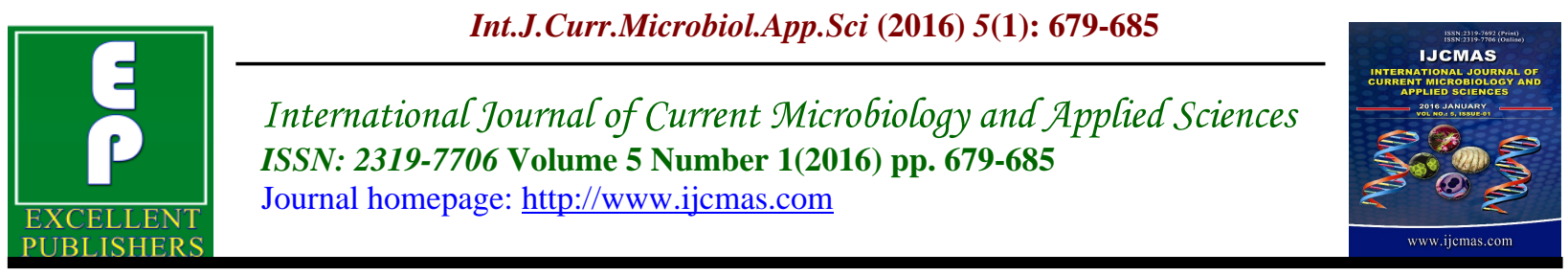

Original Research Article

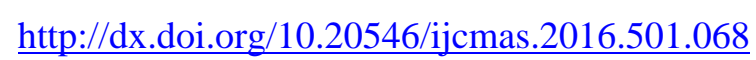

\title{
Seasonal Fluctuations among the Fungal Associates of Rhododendron campanulatum D.Don.
}

\author{
Shilpa, Anand Sagar and Nisha Rani* \\ Department of Biosciences, Himachal Pradesh University, Shimla - 171005 (H.P), India \\ *Corresponding author
}

\begin{abstract}
A B S T R A C T
Keywords

Rhizosphere,

Fungi,

AM spore,

Endophytes,

Rhododendron

campanulatum

Article Info

Accepted:

25 December 2015

Available Online:

10 January 2016

The present study was undertaken to investigate the fungal associates of Rhododendron campanulatum D. Don from Churdhar region of District Shimla and Sirmaur in Himachal Pradesh. Studies revealed the presence of seven species of fungi belonging to six genera (Absidia, Aspergillus, Curvularia, Fusarium, Pythium and Trichoderma) from mycorrhizosphere soil of Rhododendron campanulatum. Fusarium was the most dominant genus among rhizosphere soil fungi. Twenty seven species of AM fungal spores belonging to eight genera (Acaulospora, Dentiscutata, Endogone, Entrophospora, Gigaspora, Glomus, Sclerocystis and Scutellospora) were isolated from the rhizosphere soil of Rhododendron campanulatum. Glomus was the most abundant genus recorded. Twenty species of endophytic fungi belonging to thirteen genera (Alternaria, Aspergillus, Baratalinia, Cephalosporium, Cunninghamella, Fusarium, Gliocladium, Macrophomina, Myrothecium, Penicillium, Phoma, Pythium and Trichoderma) were isolated from the leaves, bark, stem and roots of Rhododendron campanulatum. Penicillium was the most dominant genus among the endophytic fungi. Maximum numbers of endophytic and rhizospheric fungi were observed during the rainy season followed by summer and winter season. Maximum numbers of VAM spores were observed during the rainy season followed by winter and summer season.
\end{abstract}

\section{Introduction}

The microbial biomass constitutes an important component of soil organic matter and it can sensitize to any change in organic inputs (Powlson et al., 1987). Interactions between plants and soil microorganisms have long been recognized for their importance in plant mineral nutrition and nutrient cycling. Mycorrhizae are beneficial for the growth because of the enhanced nutrient uptake. Endophytes are the microbes such as Fungi and bacteria that survive with their hosts without producing any apparent symptoms or negative effects (Hirsch and Braun, 1992). Fungi are most frequently isolated endophytes and known to produce polysaccharides, enzymes or proteins and secondary metabolites. One more group of fungi is VAM which enhance 
the uptake of nutrients, especially phosphorus (Hayman, 1975), promote the plant growth, improve plant tolerance to drought and toxicity of pollutants (Bedini et al., 2007: Zareri et al., 2010), resistance against pathogens (Davis and Menge, 1982) and increase the absorptive surface area of roots.

One of the most fascinating hot spots of activity and diversity in the soil is rhizosphere (Hinsinger, 2005). The plant rhizosphere favour the growth of microorganisms and provide a critical link between the plant and soil environments (Qian et al., 1998). Rhizosphere microorganisms produce plant growth hormones such as Indole Acetic acid (IAA), Gibberllins and Cytokinins (Tien et al., 1979).

A brief review of literature revealed the work on rhizosphere fungi, endophytes and VAM association of different plants like Adhatoda vasica, Picea smithiana, Ocimum sanctum, Rhododendron arboreum and Taxus baccata but the fungal associates of Rhododendron campanulatum are not fully explored. Rhododendron campanulatum D.Don belongs to family Ericaceae is economically and medicinally very important in North-West, India.

Rhododendrons and their habitats are facing tremendous threats both due to natural as well as anthropogenic reasons. Flower is edible and harvested for making chutney and squash, consequently seed formation and seed dispersal is effected resulting significant decline in populations and species diversity of Rhododendrons. As a result more species will become endangered, rare and threatened in future. Hence the present work was undertaken to investigate the fungal associates of Rhododendron campanulatum D.Don
Materials and Methods

\section{Materials}

Native to India Rhododendron campanulatum is a shrub or small tree upto $5 \mathrm{~m}$ high, and widely distributed in Himalayan regions from Jammu \& Kashmir to Sikkim, at an altitudes between 2400 and $5200 \mathrm{~m}$. Material used in this study were roots, leaves, stem, bark and soil samples from rhizosphere of this plant. The samples were collected form Churdhar region of District Sirmaur and Shimla, Himachal Pradesh. The collections were made during summer, rainy and winter season.

\section{Methodology}

\section{Isolation of Rhizosphere and Endophytic Fungi}

For the isolation of rhizosphere fungi, dilution plate method of Wakesman (1927) and Warcup (1950) was followed. The media used for culturing rhiozospheric fungi were Czapeks Dox (Raper and Thom, 1949) and Potato Dextrose Agar (Rawling, 1933). Fungal endophytes were isolated from leaf, stem, bark and root samples of Rhododendron campanulatum following three step method of Suryanarayanam and Rajagopal (2000). The isolated fungi were identified following Nagamani et al. (2006)

\section{Isolation of AM Fungal Spores}

"Wet Sieving and Decanting Technique" (Gerdman and Nicolson, 1963) was used for isolation of AM spores. The criteria employed for identification were colour, size, shape, wall characteristics, contents and surface ornamentation of spores. The identification was done following Trappe (1982) and Schenck and Perez (1988). AM infection in roots was assessed by following 
the method of Philips and Hayman (1970).

\section{Results and Discussion}

Seven species of fungi belonging to six genera (Absidia cylindrospora, Aspergillus niger, Curvularia prasadii, Fusarium moniliforme, Fusarium solani, Pythium sp. and Trichoderma viride) were isolated from the mycorhizosphere soil samples of Rhododendron campanulatum (Table1). Fusarium was most predominant genus reported in present investigation. Lakhanpal and Kumar (1984) isolated Aspergillus spp., Penicillium spp. and Trichoderma spp. from the mycorrhizosphere of Picea smithiana. Thakur and Sagar (2007) studied the microbial associates of Terminalia chebula and Embilica officinalis and isolated Aspergillus, Fusarium, Trichoderma and Penicillium. Similar genera have been recorded in the present investigation. Sagar et al. (2015) screened rhizospheric soil samples of Triticum aestivum and revealed the presence of 18 species of fungi belonging to genus Aspergillus, Fusarium and Absidia and maximum genera isolated were belongs to division Deuteromycota.

Twenty species of endophytic fungi belonging to thirteen genera (Alternaria alternata, Aspergillus niger, Baratalinia sp., Cephalosporium acremonium, Cunninghamella elegans, Fusarium moniliforme, Fusarium oxysporum, Fusarium solani, Gliocladium catenulatum, Macrophomina phasioli, Myrothecium roridum, Penicillium chrysogenum, $P$. citrinum, $\quad P$. griseofulvum, $P$. purpurogenum, $P$. restrictum, Phoma sp., Pythium sp., Trichoderma harzianum and $T$. viride) were isolated from the bark, roots, stem and leaves of Rhododendron campanulatum (Table 2). Penicillium was found to be the most dominant genera in the present investigation.
The rhizospheric and endophytic fungal isolates were further grouped into Eumycota, Zygomycota, Ascomycota and Deuteromycota. The maximum isolates from the present study belongs to Deuteromycota. This could be attributed to the reason that 'Fungi imperfecti' can tolerate wider environmental conditions as compared to other fungal populations (Behra and Mukerji, 1984).

A comparison of seasonal distribution of these rhizospheric and endophytic fungal isolates from Rhododendron campanulatum revealed that maximum number of fungi were recorded in rainy season, followed by summer season and winter season respectively (Fig. 1). Sagar and Kaur (2010) isolated the rhizospheric fungi of Aesculus indica and recorded maximum number of fungi during rainy season, followed by spring, winter and summer season. It is attributed to the fact that variation in individual fungal species distribution depends upon the type of soil, moisture content of soil, depth, season of the year, concentration of organic matter. Isolation procedure employed also influences the microbial distribution around the root surface (Atkinson, 1980; Subrahmanyam, 1990 and Mohan et al., 1995).

Twenty seven species of VAM fungal spores (Acaulospora delicata, A. foveata, $A$. minuta, A. scrobiculata, A. tuberculata, Dentiscutata nigra, Endogone sp., Entrophospora colombiana, Gigaspora gigantea, G. margarita, G. rosea, Glomus ambisporum, G. clarum, G. clavoideum, $G$. fasiculatum, G.glomerculatum, G. halon, $G$. macrocarpum, G. microsporum, $G$. mosseae, G. occultum, G. rubiforme, $G$. spurcum, G. verrucosa, Sclerocystis sp. and Scutellospora minuta) were isolated from the root adhering soil of Rhododendron campanulatum (Table 3 ). 
Table.1 List of Fungi Isolated from Rhizosphere Soil Samples of Rhododendron campanulatm D. Don

\begin{tabular}{|l|l|l|}
\hline Sr. no. & Division & Name of fungus isolated \\
\hline 1. & Eumycota & Pythium sp. \\
\hline 2. & Zygomycota & Absidia cylindrospora \\
\hline 3. & Ascomycota & Aspergillus niger \\
\hline 4. & Deuteromycota & $\begin{array}{l}\text { Curvularia prasadii, Fusarium } \\
\text { moniliforme, F. solani, } \\
\text { Trichoderma viride. }\end{array}$ \\
\hline
\end{tabular}

Table.2 List of Endophytic Fungi Isolated from Bark, Leaves, Roots and Stem of Rhododendron campanulatum D. Don

\begin{tabular}{|l|l|l|}
\hline Sr.no. & Division & Name of fungus isolated \\
\hline 1. & Eumycota & Pythium sp. \\
\hline 2. & Zygomycota & Cunninghamella elegans \\
\hline 3. & Ascomycota & $\begin{array}{l}\text { Alternaria alternata, Aspergillus niger, } \\
\text { Penicillium chrysogenum, P. citrinum, P. } \\
\text { griseofulvum, P. purpurogenum, P. restrictum, } \\
\text { Phoma sp. }\end{array}$ \\
\hline 5. & Deuteromycota & $\begin{array}{l}\text { Baratalinia sp., Cephalosporium acremonium, } \\
\text { Fusarium moniliforme, F. oxysporum, F. solani, } \\
\text { Gliocladium catenulatum, Macrophomina } \\
\text { phasioli, Myrothecium roridum, Trichoderma } \\
\text { harzianum, T. viride. }\end{array}$ \\
\hline
\end{tabular}

Table.3 List of VAM Fungal Spores Isolated from the Rhizosphere Soil Samples of Rhododendron Campanulatum D. Don

\begin{tabular}{|c|l|l|}
\hline Sr. No. & Genus & Species \\
\hline 1. & Acaulospora & $\begin{array}{l}\text { A. delicata, A. foveata, A. laevis, A. minuta, } \\
\text { A. scrobiculata, A. tuberculata }\end{array}$ \\
\hline 2. & Dentiscutata & D. nigra \\
\hline 3. & Endogone & Endogone sp. \\
\hline 4. & Entrophospora & E. colombiana \\
\hline 5. & Gigaspora & G. gigantea, G. margarita, G. rosea \\
\hline 6. & Glomus & $\begin{array}{l}\text { G. ambisporum, G. clarum, G. clavoideum, } \\
\text { G. fasiculatum, G. glomerculatum, G. halon, } \\
\text { G. macrocarpum, G. microsporum, G. } \\
\text { mosseae, G. occulatum, G. rubiforme, G. } \\
\text { spurcum, G. verrucosa }\end{array}$ \\
\hline 7. & Sclerocystis & Sclerocystis sp. \\
\hline 8. & Scutellospora & S.minuta \\
\hline
\end{tabular}


Fig.1 Seasonal Distribution of Rhizospheric Fungi, Endophytic Fungi and VAM Spores of Rhododendron campanulatum D. Don

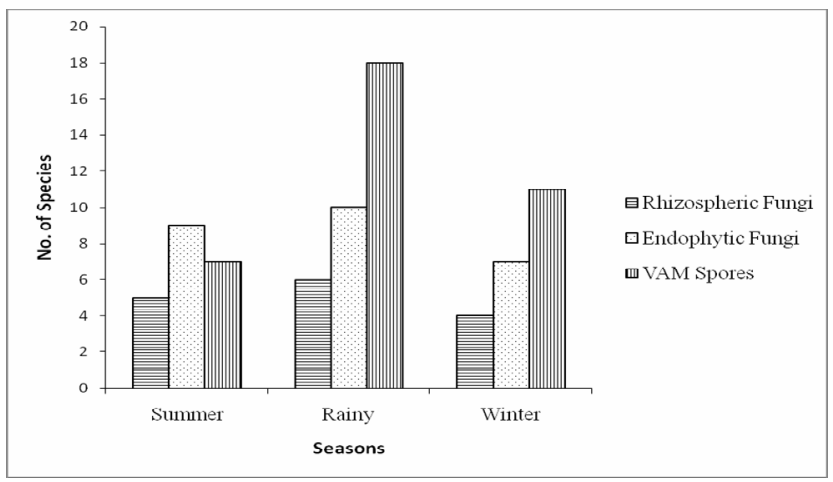

These fungal isolates were further grouped into Zygomycota and Glomeromycota. The maximum isolates from the present study belongs to the Glomeromycota and genus Glomus. Kaur et al. (1997) studied the VAM associates of Celtis australis and Grewia optiva and reported the genus Glomus to be more dominant in Himachal Pradesh soils. Tamuli and Boruah (2002) isolated two genera Glomus and Sclerocystis from the rhizosphere soil samples of Agarwood. They found Glomus as most frequent VAM fungus in their investigation. Rani et al. (2008) isolate 29 species of AM fungi associated with 15 medicinal and ornamental plants belonging to Asclepidaceae. Glomus was found to be the most dominant genus and represented by 15 species. Sagar et al. (2015) isolated 15 species of VAM fungal spores belonging to six genera with Glomus as dominant (Acaulospora, Glomus, Claroideoglomus, Dentiscutata, Scutellospora and Gigaspora) from the soil samples of Triticum aestivum from normal and disturbed field of Darlaghat, Himachal Pradesh, India

A comparison of seasonal distribution of these isolates revealed that maximum numbers of fungal spores were recorded in rainy season, followed by winter season and summer season respectively (fig. 1). This variation may be attributed to the fact that
VAM colonization is found to be decreased in winter and summer and reached to maximum in the rainy season (Sharma et al., 2005).

The present investigations are of preliminary type, yet have established a base for future exploitation of these fungal associates (rhizosphere and VAM fungi) for mass multiplication of nursery seedlings, growth and productivity of $R$. campanulatum as well as commercial production of secondary metabolites from endophytes.

\section{Acknowledgement}

Authors are thankful to UGC, New Delhi, India for financial assistance in the form of UGC-PDFW fellowship as well as to the Chairperson, Deptt. of Biosciences, H.P.U. Shimla for providing laboratory facilities.

\section{References}

Atkinson, D. 1980. The distribution and effectiveness of roots of tree crops.Hort. Rev. 2: 424-490.

Bedini, S., Avio, L., Argese E, Giovanneti, M. (2007). Effects of long- term land used on arbuscular mycorrhizal fungi and glomalin- related soil protein. Agric. Ecocyst. Environ. 120: 463466. 
Behra, N. and Mukerji, K.G. 1984. Studies on the soil microfungi in relation to edaphic factors. Act. Bot. Ind. 12: 153-156.

Davis, R.M. and Menge, J.A. 1981. Phytopathora parasitica and intensity of vesicular arbuscular mycorrhizae in citrus. New Phytol. 87: 705- 715 .

Gerdemann, J.W. and Nicolson, T.H. 1963. Spores of mycorrhizal Endogone species extracxted from soil by wet sieving and decanting technique. Trans. Br. Mycol. Soc. 46: 235-244.

Hayman, D.S., Johnson, A.M. and Ruddlesdin, I. 1975.The influence of phosphate and crop species on endogone spores and vesiculararbuscular mycorrhizae under field conditions. Plant Soil.41: 489-495.

Hinsinger, P., Gobran, G.R., Gregory, P.J. and Wenzel, W.W. 2005.Rhizosphere geometry and heterogeneity arising from rootmediated physical and chemical processes. New Phytol. 168: 293303.

Hirsch, G.U. and Braun, U. 1992. Fungi in vegetation science, In: Handbook of vegetation science (Ed. W. Winterhoff). Kluwer, Dordrecht. 19: 225-250.

Kaur, M.J., Sagar, A. and Lakhanpal, T.N. (1997). Observations on vesicular arbuscular mycorrhizal associations of Grewia optiva. J. Mycol. Pl. Pathol. 27: 323-324.

Lakhanpal, T.N and Kumar, S. (1984). Influence of ectomycorrhiza on growth and elemental position of Piceasmithiana seedlings. J. Tree Sci. 2: 38-41.

Mohan, V. and Neelam Singh, Y.P. 1995. Distribution of VAM fungi in nurseries and plantation of neem (Azadirachtaindica) in arid zone of
Rajasthan. Ind. For. 121: 1069-1076.

Nagamani, A., Kunwar, I.K. and Manoharachary, C. (2006). Handbook of Soil Fungi. I.K. International publishrers. 477.

Phillips, J.M. and Hayman, D.S. 1970. Improved procedures for clearing roots and staining parasitic and VAM fungi for rapid assessment of infection. Trans. Br. Mycol. Soc. 55: $158-161$.

Powlson, D. S., P. C. Brookes and B.T. Christen, 1987. Measurement of soil microbial biomass provides an early indication of changes in total soil organic matter due to straw incorporation. Soil Biology and Biochemistry. 19:159-164.

Qian, X.M., Ashker, A.E.I., Kottke, I. and Oberwinlker, F. 1998. Studies of pathogenic and antagonistic micro fungal population and their potential interaction in the mycorrhiza-plane of Norway Spruce (Picea abies L.) and beech (Fagus slvatica L.) on acidified and limed plots. Plant and soil. 199 : 111-116.

Rani , S.S., Manoharachary, C. and Kumar, I.K. 2008. Arbuscular mycorrhizal fungi associated with some plants of Asclepidaceae. J.Mycol. Pl. Pathol. 38: 534-536.

Raper, K.B. and Thom, C. 1949.A manual of Pencilia. Williams and Wilkins company, Baltimore. p. 875.

Rawling, T.E. 1933. Phytopathologial and botanical research methods. John Wiley and Sons. London.

Thakur, M. and Sagar, A. 2007. Fungal associates of Terminalia chebula, Terminalia bellirica and Embilica officinalis. J. Of Pure and App. Micro. 1: 301-306.

Sagar, A. and R. Kaur (2010). Study on fungal associates of Aesculus indica. Biological Forum- An International 
Journal. 2: 49-52.

Sagar, A., Shivani and Rani, N. 2015. Biodiversity of VAM and Rhizosphere fungi associated with wheat grown in normal and disturbed field of Darlaghat, Himachal Pradesh, India. Plant Archives. 15: 549- 533.

Schenk, N.C. and Perez, Y. 1988. Manual of identification of VAM fungi. University of Florida, USA. pp. 124.

Sharma, S., Aggarwal, A., Prakash, V. and Mehrotra R.S. 2005. Seasonal population dynamics of VAM fungi associated with Tectona grandis L. and Dendrocalamus strictus (Roxb.) Nees. Indian Phytopath. 58: 163166.

Subhrahmanyam, A. 1990.Ecology and distribution. In: Thermophilicmoulds academic publishers, Netherlands.

Suryanarayan, T.S. and Rajagopal, K. 2000. Fungal endophytes of some tropical trees.Ind. For. 126: 165-170.

Tamuli, P. and Boruah, P. 2002. Vesicular arbuscular mycorrhizal (VAM) association of agarwood tree in Jorhat district of the Brahamputra valley. Ind. For. 128: 991-994.

Tien , T.M., Gaskins, M.H. and Hubbell, D.H. 1979. Plant growth substances produced by Azospirillium brasilense and their effect on the growth of pearls millet (Pennisetum americanum L.) Appl. Environ. Microbiol. 37: 1016-1024.

Trappe, J.M. 1982. Synoptic key to the genera and species of Zygomycetous mycorrhizal fungi. Phytopathol. 72: 1102-1108.

Wakesman, S.A. (1927). Principles of soil microbiology. Williams and Wilkinson Company Baltimore.

Warcup, J.H. (1950). The soil plate method for isolation of fungi from soil. Nature.166: 117-118.

Zareri, M., Hempel, S., Wubet, T., Schafer, T., Savaghebi, G., Jouzani, G.S., Nekouei, M.K. and Buscot, F. (2010). Molecular diversity of AM fungi in relation to soil chemical properties and heavy metal contamination. Environ. Pollut. 158: 2757-2765.

\section{How to cite this article:}

Shilpa, Anand Sagar and Nisha Rani. 2016. Seasonal Fluctuations among the Fungal Associates of Rhododendron campanulatum D.Don. Int.J.Curr.Microbiol.App.Sci. 5(1): 679-685 ihttp://dx.doi.org/10.20546/ijcmas.2016.501.068 